\title{
Potential for Protection and Repair Following Injury to the Developing Brain: A Role for Erythropoietin?
}

\author{
AUGUSTO SOLA, TONG-CHUN WEN, SHANNON E.G. HAMRICK, AND DONNA M. FERRIERO \\ Division of Neonatal-Perinatal Medicine [A.S., T.C.W.], Emory University School of Medicine, Atlanta, \\ Georgia, 30322, Department of Pediatrics and Neurology [S.E.G.H., D.M.F.], University of California at \\ San Francisco, San Francisco, California, 94143
}

\begin{abstract}
Perinatal brain injury is a major contributor to perinatal morbidity and mortality, and a considerable number of these children will develop long term neurodevelopmental disabilities. Despite the severe clinical and socio-economic significance and the advances in neonatal care over the past twenty years, no therapy yet exists that effectively prevents or ameliorates detrimental neurodevelopmental effects in cases of perinatal/neonatal brain injury. Our objective is to review recent evidence in relation to the pervading hypothesis for targeting time-dependent molecular and cellular repair mechanisms in the developing brain. In addition we review several potential neuroprotective strategies specific to the developing nervous system, with a focus on erythropoietin (Epo) because of its potential role in protection as well as repair.
\end{abstract}

(Pediatr Res 57: 110R-117R, 2005)

\author{
Abbreviations \\ AMPA, amino-3-hydroxy-5-methylisoxazole-4-propionic acid \\ BBB, blood brain barrier \\ Bcl-xL, antiapoptotic gene B-cell lymphoma-x long \\ CP, cerebral palsy \\ Epo (R), erythropoietin (receptor) \\ FCI, focal cerebral ischemia \\ HI, hypoxia-ischemia \\ IVH, intraventricular hemorrhage \\ Jak2, Janus kinase-2 \\ NF- $\boldsymbol{\kappa} \mathbf{B}$, nuclear factor $-\kappa \mathrm{B}$ \\ NMDA, $N$-methyl-D-aspartate \\ NO, nitric oxide \\ PVL, periventricular leukomalacia \\ PVWM, periventricular white matter \\ Stat5, the signal transducer and activator of transcription-5
}

\section{INJURY TO THE DEVELOPING BRAIN AND POTENTIAL THERAPIES}

Brain injury in term infants. Between 20 and $50 \%$ of infants affected by neonatal brain injury die during the neonatal period, and $30-60 \%$ of the survivors suffer long-term sequelae, including $\mathrm{CP}$, seizures, mental retardation, and learning disabilities (1). The incidence is not decreasing and has even been shown to increase in some areas without significant decrease in $\mathrm{CP}$ in the last $30 \mathrm{y}(2,3)$. Acquired problems in term infants manifesting neonatal encephalopathy are damage due to trauma, seizures, infection, HI, and stroke.

Perinatal stroke involving the middle cerebral artery has been reported to occur commonly in term infants $(4-8)$. The incidence of perinatal FCI is higher than previously recognized and may be more prevalent than global cerebral damage arising from systemic asphyxia or infection. Symptomatic perinatal

Received December 15, 2004; accepted January 14, 2005

Correspondence: Augusto Sola, M.D., Division of Neonatal-Perinatal Medicine, Department of Pediatrics, Emory University School of Medicine, 2015 Uppergate Dr, Atlanta, GA 30322; e-mail: asola2@emory.edu

Supported in part by the Children's Research Center and a Goddard Scholarship, Emory University (A.S., T.C.W.). stroke occurs in about 1 in 4000 term neonates (4,5). However, many cases may go unrecognized inasmuch as early imaging studies like head ultrasound may be unrevealing in neonates with cerebral infarction (6), and early hospital discharge may preclude in-hospital diagnosis in asymptomatic newborns. Risk factors usually identified in epidemiologic investigations have been recently reviewed in detail (7). In a cohort of 124 encephalopathic term infants, 6 infants with acute FCI presented with seizures, and their neurodevelopmental outcome at 30 mo was severely abnormal (8), demonstrating that acute focal stroke is a serious occurrence in newborns who may inadvertently receive a diagnosis of hypoxic ischemic encephalopathy.

Brain injury in preterm infants. In addition to $\mathrm{HI}$ and stroke, IVH, PVL, and ventriculomegaly are recognized disturbances in brain structures in preterm infants resulting from a variety of genetic and acquired causes. Each year in the United States, about 57,000 very low birthweight infants $(<1500 \mathrm{~g})$ are born, 90\% survive, and approximately $10 \%$ of the survivors show signs of CP, and an additional 25-50\% display cognitive or behavioral deficits (9). For the extremely low birth-weight infants the problem is worse, because about $25 \%$ of infants with birth weight $500-750 \mathrm{~g}$, and more than 
$10 \%$ of those weighing $750-1000 \mathrm{~g}$ develop severe IVH (10) associated with high mortality rate, major motor deficits, and significant cognitive delay. Cerebral hypoperfusion, chronic hypoxia, poor cerebral autoregulation, and free radical production can lead to necrosis, cystic formation, and gliosis of white matter surrounding the ventricles. In addition to IVH and PVL, there are changes that result from interference with normal brain development. Many preterm infants with neurodevelopmental handicaps have no evidence of any clastic lesion by clinical history and imaging, suggesting that preterm birth and the complicated postnatal course disrupts many cellular and subcellular mechanisms and also the genetically programmed brain genesis.

Mechanisms of brain injury. The mechanisms of injury, distinct patterns of injury, and selective vulnerability and increased susceptibility to oxidative damage after $\mathrm{HI}$ in term infants have been reviewed recently (11-15). The injury produced by many of these insults evolves over days, if not weeks, in different regions and cell types. The extension of the damage is directly associated with the nature and intensity of the injury (16-18). Neuronal cell damage occurs not only through necrotic but also through apoptotic processes. In necrosis, cell death is triggered by an overwhelming external insult damaging cellular organelles such as mitochondria. This results in the loss of membrane integrity and the leakage of cytoplasmic contents into the extracellular matrix. In contrast, cells dying by apoptosis undergo a well-conserved and highly regulated genetic program of cell death, do not lose membrane integrity, and the organelles remain largely intact. This process, which largely circumvents inflammatory reactions, is a biochemically and genetically programmed cell death that requires time, energy, and, to a certain extent, new gene transcription and translation. One pathway that is implicated in apoptotic cell death is the release of cytochrome $c$ from the mitochondria through the permeability transition pore. This pore is controlled by the antiapoptotic B-cell lymphoma-2 (Bcl-2) proteins. Once in the cytosol, cytochrome $c$ can lead to the activation of caspase- 8 and caspase- 9 that cleaves vital proteins and triggers apoptotic execution by activating downstream caspases and endonucleases. A broad range of signal transduction systems regulate integration of cellular function and plasticity, as well as cell survival and injury. Many of these processes have been shown to be significantly involved in secondary neuronal cell death after perinatal hypoxic ischemic insults. When mild, such insult causes no ATP reduction, a moderate insult causes biphasic depletion and subsequent apoptosis, and a severe insult causes energy failure followed by massive necrosis.

A second wave of neuronal cell damage occurs during the reperfusion phase induced by the postischemic release of oxygen radicals, synthesis of NO, inflammatory reactions, and an imbalance between the excitatory and inhibitory neurotransmitter systems. In HI, recent studies have provided not only insight into the time course of injury evolution both in animals and humans, but have demonstrated a greater role of oxidant stress and inflammation. The role for inflammation has been derived from epidemiologic data, which has linked inflammatory mediators with cerebral palsy. The interplay of cytokines and HI can worsen an injury, as suggested by cytokine levels that when elevated were significantly predictive of the development of cerebral palsy. Infants born to mothers with chorioamnionitis have high levels of IL-6, and those who develop hypoxic ischemic encephalopathy or seizures have significantly higher concentrations of IL- 6 and IL- 8 at $6 \mathrm{~h}$ (19). The spectrum of neurologic abnormalities correlated with increasing cytokine concentration. These and other data suggest that inflammation may be in the causal pathway as an antecedent of cerebral palsy. Whether this is reactive or causal is not currently fully known.

The intrinsic mechanisms of autoregulation and the vulnerability of the white matter vary in relation to gestational age. Experimental administration of glutamate agonists acting on NMDA or AMPA/kainate receptors causes a pattern of brain damage that is related to the stage of brain maturation. Lesions induced with ibotenate (glutamate agonist acting on NMDA) mimicked several brain lesions observed in human fetuses and neonates, including neuronal migration disorders, polymicrogyria, cystic PVL, and HI (20-22). Based on recent findings, it is possible that, in preterm infants, transient expression of NMDA receptors by white matter macrophages could participate in the vulnerability of the PVWM to perinatal insults $(23,24)$. Furthermore, the vulnerability of oligodendrocytes to glutamate agonists activating AMPA or AMPA-kainate receptors has been reported $(9,23-25)$. These agonists produce PVWM lesions mimicking human PVL $(23,25)$, and intracerebral injection of AMPA agonists induces massive death of oligodendrocytes in the PVWM (25) as well as suppression of oligodendroglial gene expression (26). The role inflammatory cytokines remains controversial in brain injury of preterm infants (27), but in animal models, IL-1 $\beta$, IL-6, IL-9, or tumor necrosis factor- $\alpha$ seem to play a role (28-33). Furthermore, toxic effects of oxygen, various neonatal intensive care unit medications, environment, and stress have been shown in the preterm developing brain (30).

In summary, the extent of injury to the developing brain and the different vulnerability at different stages of development have been described. Studies have identified potential targets for protection and repair aimed at both neurons and oligodendrocytes.

Potential therapies. Many investigations have been performed trying to identify potential protective therapies, based on the pathogenesis of injury, including maintenance of energy stores or the integrity of the neuronal membrane such as hypothermia, magnesium, fructose 1-6-bisphosphate, antioxidants, and inhibition of degradative exzymes (xanthine oxidase), microglial activation, and NO (31-50). It has been reported that IL-10 blunts the toxic effect of IL- $1 \beta$ pretreatment (31), and that therapeutic targeting of mast cells with inhibitors of mast cell degranulation and antihistamine drugs are protective in neonatal murine brains exposed to IL-9 before ibotenate excitotoxic insult $(32,33)$. Allopurinol (a xanthine oxidase inhibitor), in a neonatal rat model of HI, completely protected brain damage from severe neuronal cell loss (34) and produced a beneficial effect on free radical formation, cerebral blood volume, and electrical brain activity without side effects in neonates treated with $40 \mathrm{mg} / \mathrm{kg}$ (35), but further studies are 
needed. An inhibitor of NO (NG-nitro-L-arginine) given to neonatal rats $1.5 \mathrm{~h}$ before an HI insult had a highly neuroprotective effect, elegantly demonstrating the neuronal toxicity of NO after cerebral ischemia (36), and a neonatal neuronal NO synthase deficient mice showed a significant reduction in cortical damage after cerebral ischemia compared with the wild type (37).

Antepartum use of magnesium sulfate is associated with lower risk for $\mathrm{CP}$ or mental retardation $(38,39)$. Postnatal magnesium at 250 or $450 \mathrm{mg} / \mathrm{kg}$ has yielded conflicting beneficial and adverse effects like hypotension and respiratory depression (40,41). Magnesium inhibits NMDA receptors and seems to block the activation of NO after cerebral ischemia (42), and clinical trials are underway. Fructose 1-6bisphosphate, an intermediary of metabolism, has been found of value in different models $(43,44)$, more so when combined with hypothermia (44). The induction of whole-body hypothermia and selective head cooling have raised interesting possibilities for neuroprotection from cerebral ischemia and have recently been reviewed elsewhere $(11,14)$. Clinical safety studies in newborn infants after perinatal asphyxia have shown no harmful side-effects (45-47), and results of larger clinical studies that are close to completion or in press $(48,49)$ will provide more detailed information about clinical efficacy and safety.

Therefore, manipulation of oxidant, antioxidant, and cell death pathways and improving the understanding of the maturational changes in developmental brain biology may lead to additional strategies for protection and repair of brain injury (50).

\section{EPO AS A NEUROPROTECTANT IN INJURY TO THE DEVELOPING BRAIN}

The protective effect of exogenously administered Epo has received much attention for adult ischemic disease, and promising data are emerging in perinatal models. We summarize the biologic role of Epo, current findings on its short- and longterm protective properties in the developing brain, signal transduction systems modulated by Epo, and mechanisms by which Epo may produce protection in the developing brain.

Biologic roles of Epo. Epo is a pleiotropic cytokine originally identified for its role in erythropoiesis. It is a $34-\mathrm{kDa}$ glycoprotein that functions as a main regulator of erythropoiesis initially thought to be exclusively produced in fetal liver and adult kidney (51). The pleiotropic functions of this hormone include modulation of inflammatory and immune response, direct hemodynamic and vasoactive effects, and proangiogenic effects by interaction with vascular endothelial growth factor and its ability to stimulate mitosis and motility of endothelial cells. Recently, Epo and EpoR were found to be expressed by other tissues, including the nervous system (5254). Epo has tissue-specific regulation and multiple actions in the CNS. Different cell types (neurons, glial cells, and endothelial cells) in the nervous system produce Epo and express EpoR, and both have been identified in specific areas of the embryonic, fetal, and adult brains of rodents, nonhuman primates, and humans. Epo and EpoR expression change significantly during brain development. High EpoR expression has been found in embryonic mouse neural tissue and brain, with a significant decrease (100-fold reduction after birth) during development and maturation of the brain (52). Additionally, the production of Epo in the human nervous system is elevated during gestation and is reduced after birth (53). Additionally, Epo is a general morphogen and inducer of neurogenesis during early development $(54,55)$. These findings indicate the importance of the Epo/EpoR system in neurodevelopment.

Activation of Epo and its receptor. Epo gene expression in most tissues, including the brain, is regulated by a variety of stressors, including hypoxia (56). It has been demonstrated that astroglial expression of Epo is greatly enhanced by hypoxia at the level of mRNA (57). Both Epo and EpoR mRNA are inducible by hypoxia in hippocampal neuronal cultures (58). Therefore, as with Epo production in the kidney and fetal liver, the effect of hypoxia on Epo production in neuronal cells is regulated in part via the transcriptional activator hypoxiainducible factor-1. In vivo hypoxia also stimulates Epo and EpoR mRNA expression in the hippocampus of adult rats $(58,59)$ and in the monkey and human brains $(60)$. Moreover, the middle cerebral artery occlusion produces an induction of EpoR gene expression in the ischemic penumbra (61), and the temporal and spatial cellular expression of Epo and EpoR with the evolution of a cerebral infarct after focal permanent ischemia in adult mice have been described (62). In addition to a basal expression of Epo in neurons and astrocytes, a postischemic Epo expression has been localized specifically to endothelial cells, microglia/macrophage-like cells, and reactive astrocytes (62). In normal adult human brain, weak Epo/EpoR immunoreactivity is mainly neuronal (63); however, after acute ischemic injury in adult human brain the expression of EpoR is up-regulated in blood vessels, neurons, and astrocytes and remains increased in reactive glia in older ischemic infarcts ( $>18 \mathrm{~d}$ after stroke). The pronounced up-regulation of Epo/ EpoR in adult human ischemic/hypoxic brains underlines their role as an endogenous protective system. In a reproducible experimental model of neonatal focal ischemia in the rat (64), we recently found that EpoR density was significantly increased on the neurons, the microglia/macrophage, and the endothelium of blood vessels, but not on the astrocytes in the ischemic cortex and striatum of P7 rats after focal stroke (65). Moreover, about $50 \%$ of EpoR-positive cells were also positive with terminal deoxynucleotidyltransferase-mediated 2'deoxyuridine 5'-triphospate-biotin nick end labeling (TUNEL) (65). Therefore, the induction of both Epo and EpoR gene expression by hypoxia and ischemia suggest that Epo could act on the CNS as a neurotrophic and protective factor.

In vitro neuroprotective effects of Epo. A growing body of literature indicates that Epo protects cultured neurons against various stressor-induced injuries. It has been shown that Epo protects primary cultured hippocampal and cortical neurons against glutamate toxicity $(62,66,67)$. Epo also ameliorates hypoxia and glucose deprivation-induced neuronal damage and reduces the toxic effects of a glutamate agonist on cultured neurons (68). Additionally, Epo protects cultured hippocampal neurons against hypoxia-induced neuronal death and inhibits the serum deprivation- or kainic acid-induced apoptosis of cultured neurons (59). A continuing search for factors that can increase neurogenesis show that Epo is a promising candidate capable of regulating the production of neuronal progenitors by 
neural stem cells both in cell culture and in situ in the adult CNS (69). The up-regulation of Epo in the CNS after hypoxia supports a role for Epo in the brain's response to injury not only acutely after injury (70), but in repopulating injured areas as well (69). Moreover, Epo attenuated neuronal damage caused by chemical hypoxia (induced by rotenone and 2-deoxyglucose) at lower extracellular concentrations $\left(10^{-4}-10^{-2}\right.$ $\mathrm{U} / \mathrm{mL}$ ) than were previously considered (71). Recently, it has been reported that Epo protects cerebrocortical neurons from human immunodeficiency virus/gp120-induced damage (72). These in vitro results provide direct potential relevance to Epo's in vivo effects.

Short- and long-term beneficial effects of Epo in experimental perinatal models. Several studies in perinatal models have recently demonstrated protective effects of Epo when Epo was administered before producing the injury (73-78). In the first of such studies published in 2003 (73), the infarct volume and apoptotic neuronal death were improved in a newborn rat HI brain injury model with intraperitoneal Epo treatment (1000 $\mathrm{U} / \mathrm{kg}$ ). The same year, additional reports showed a neuroprotective effect in the same $\mathrm{HI}$ rat model (74) and a reduction in infarct size in mice treated with Epo $24 \mathrm{~h}$ before experimental infarction (75). When used at very high doses, up to approximately $20,000-30,000 \mathrm{U} / \mathrm{kg}$ (76) starting $24 \mathrm{~h}$ before experimental neonatal $\mathrm{HI}$ injury in the rat and followed by daily dosing, Epo prevented HI-induced DNA fragmentation (77). It has also been found that Epo prevents intrauterine ischemia reperfusion-induced fetal brain damage in rats (78). Importantly, a study has reported beneficial effects with Epo gene therapy. A single intravenous injection of naked plasmid containing Epo cDNA driven by cytomegalovirus promoter given to hypoxic ischemic infant rats increased Epo levels, which peaked at $1 \mathrm{~d}$ and lasted for $14 \mathrm{~d}$ (79). In our model (64), three Epo doses were given after a focal ischemic stroke in the region supplied by the middle cerebral artery. This significantly reduced the mean infarct area, the mean infarct volume, and the number of TUNEL-positive cells in the ipsilateral ischemic cortex in a dose-dependent manner (80), providing more practical meaning to Epo treatment for stroke in human neonates. Of the three doses studied, the most useful dose to decrease the lesion size, protect the neonatal brain against focal cerebral ischemic insult, and attenuate the effects of stroke in neonatal rats with FCI was $1000 \mathrm{U} / \mathrm{kg}(80)$.

A recent report has shown that Epo administration at a single dose immediately after HI injury significantly improves longterm spatial memory deficits at $20 \mathrm{wk}$ and reduces the infarct volume at $21 \mathrm{wk}$ after $\mathrm{HI}$ in $\mathrm{P} 7$ rats (81). More importantly, the brain in the Epo-treated animal shows slight hypotrophy in the ischemic hemisphere whereas the brain in the saline-treated animal exhibits severe atrophy and cortical cavities at $21 \mathrm{wk}$ after HI. Also, our unpublished data have shown that the beneficial effects of Epo given post FCI injury in reducing infarct area and volume can last for $12 \mathrm{wk}$ after FCI, and a very recent study also shows significant improvement in long-term outcome (82).

Collectively, this evidence suggests that Epo may provide a new approach to the treatment of a variety of CNS disorders in adults and children and could become a therapeutic agent in perinatal asphyxia and stroke and in the prevention of injury in the premature developing brain.

Mechanisms of action of Epo. The biologic effects of Epo in the CNS involve activation of its specific receptor and corresponding signal transduction pathways. Although the precise molecular mechanism underlying the neuroprotective effects of Epo has not been completely elucidated, less so in the developing brain, Epo may act at multiple levels. The potential protective effects include generation of neuronal antiapoptotic factors and antiapoptotic mechanisms (83), prevention of oxidative damage (78) with direct antioxidant effects via activation of antioxidant enzymes and inhibition of lipid peroxidation, decrease of NO-mediated injury by inhibition of $\mathrm{NO}$ production (84), stimulation of angiogenesis (85), modulation of neurogenesis (69), reduction of glutamate toxicity (57), and reduction of inflammation with antiinflammatory effects (86). The mechanisms that have been involved in Epo-induced neuroprotection are summarized in Table 1, and the potential actual antiapoptotic mechanisms of Epo are shown in Figure 1. In non-neuronal cells, the evidence indicates that the antiapoptotic effects of Epo are mediated by activating Jak2, leading to tyrosine phosphorylation of Stat5 and the up-regulation of antiapoptotic genes (87). Jak2 and Stat5 are expressed in various brain regions including cortex, hippocampus, and striatum during embryonic and postnatal stages (87), suggesting these protein kinases may be involved in brain development. Epo attenuates glutamate release from cultured cerebellar granule cells and hippocampal neurons, protecting hippocampal neurons from ischemic neuronal damage through activation of Jak2 (88) and prevents cultured cerebrocortical neuronal death by triggering cross-talk between Jak2 and NF- $\kappa \mathrm{B}$ signaling pathways (83). We recently found that these events also occur in neonatal brains with FCI. Exogenous Epo at $1000 \mathrm{U} / \mathrm{kg}$ activated p-Jak2, p-Stat5, and the anti apoptotic gene Bcl-xL in the ischemic cortex of neonatal rats at 1 and $3 \mathrm{~d}$ after FCI (80). On the other hand, NF- $\kappa \mathrm{B}$ expression in the cortex was not altered by FCI or Epo treatment from 1 to $7 \mathrm{~d}$ after FCI (80). Whether Epo treatment activates NF- $\kappa \mathrm{B}$ 's transcriptional activating function in the developing brain needs to be verified. These findings provided insights regarding molecular mechanisms involved in the neuroprotection of Epo in the developing brain and suggest that Epo enhances neuronal survival through activation of Jak2-Stat5 pathways, which leads to activation of down-stream cellular neuroprotective genes like Bcl-xL.

Table 1. Possible mechanisms of Epo-induced neuroprotection

- Prevention of glutamate-induced toxicity

- Inhibition of apoptosis

- Antiinflammatory effects

- Antioxidant effects

- Inhibition of NO production

- Stimulation of angiogenesis

- Modulation of neurogenesis

- Prevention of the loss of autoregulation of cerebral blood flow

- Maintenance of mitochondrial membrane potential (by activating protein kinase B)

- Inhibition of caspase-3 formation and cytochrome c release

- Stimulation of survival promoting pathways such as NF- $\kappa \mathrm{B}, \mathrm{Bcl-xL}$, Akt1, heat shock protein 27, superoxide dismutase (SOD), and inhibitor of apoptosis protein (IAP), extracellular signal-regulated kinase (ERK) 


\section{Intracellular signaling pathways modulated} by Epo in the injured brain

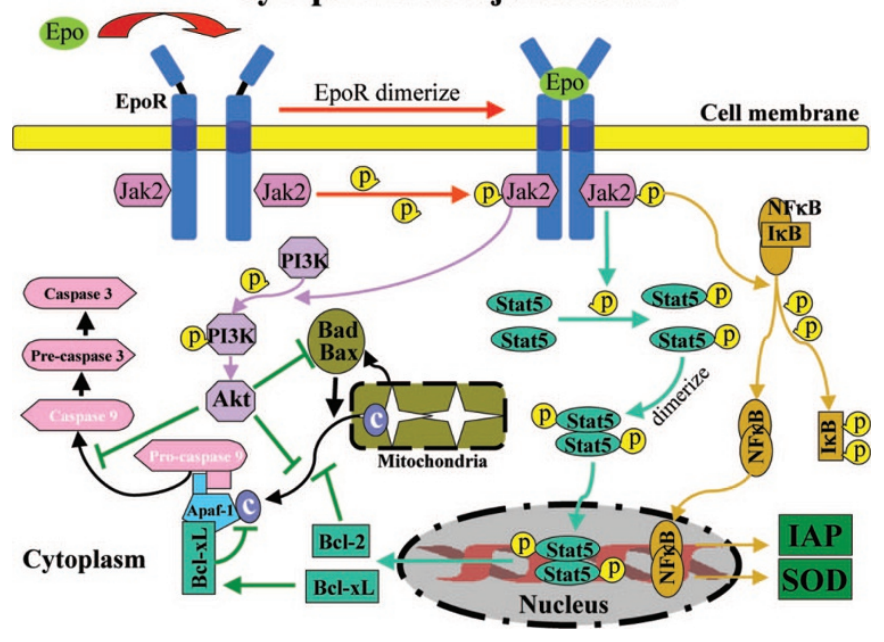

Figure 1. The intracellular signaling events of Epo after binding to EpoR in neuronal cells is shown in a schematic illustration. Epo activates phosphorylation of Jak-2 via binding to its receptor, then mediates phosphorylation of Stat-5 and activates NF- $\kappa$ B. Stat- 5 translocates to the nucleus and binds to DNA, promotes Bcl-xL and Bcl-2 expression, and finally inhibits caspase-3 activation. On the other hand, NF- $\kappa \mathrm{B}$ promotes the expression of neuroprotective genes such as IAP and SOD after it translocates to the nucleus. IAP, inhibitor of apoptotic protein; SOD, superoxide dismutase.

Receptor responses for Epo's neuroprotection. It is known that binding of Epo to its receptor ultimately results in the activation on cellular downstream signals, but an important issue to be addressed is whether the neuroprotective effects of Epo are always initially triggered by its binding to its receptor. Interestingly, hematopoietic effects of Epo are mediated by the homodimeric EpoR, whereas the receptor complex mediating its neuroprotective effects differ with respect to apparent affinity for Epo, molecular weight, and associated proteins (51). Additionally, it has been reported that a region of Epo not within the classical EpoR binding domains may be associated with protective effects in the CNS (89) and that carbamylated Epo or certain Epo mutants that did not bind to the classical EpoR were still cytoprotective in vitro and neuroprotective in vivo (90). These observations suggest that another receptor is at least partially responsible for the tissue-protective actions of Epo. Actually, Epo membrane receptors are each composed of a unique $\alpha$ subunit (the classical EpoR, which is required for erythropoiesis) and a common $\beta$ subunit ( $\beta \mathrm{cR}$, which is not required for erythropoiesis). Recent data support a concept that EpoR and $\beta \mathrm{cR}$ comprise a tissue-protective heteroreceptor (91). Interestingly, in our recent experiments in Epo-treated pups, we did not detect any significant alteration in the classical EpoR expression in the ischemic cortex from 1 to $7 \mathrm{~d}$ after FCI compared with vehicle-treated pups (80). However, further experiments are needed to determine whether exogenous Epo binds to its receptor within the first $24 \mathrm{~h}$ after FCI, preventing subsequent Epo-R up-regulation, or if the classic Epo-R is not involved in mediating the neuroprotective effects of exogenous Epo. Additionally, in a neurotoxic model induced by the NMDA receptor antagonist dizocilpine (MK801) in P7 rats, Epo protected the neonatal brain but did not alter EpoR mRNA levels in the rats given MK801 (92). Furthermore, in a neonatal $\mathrm{HI}$ model, Epo application for $3 \mathrm{~d}$ did not down-regulate EpoR, but rather prolonged EpoR expression in the cortex (76). Thus, the protective effect of exogenous Epo may be partly attributed to restoration of endogenous Epo signaling and may not be associated with the classical EpoR.

Potential for adverse events with Epo treatment. The application of Epo for neonates with perinatal asphyxia, stroke, or those preterm with complicated postneonatal courses has not yet been tested clinically. Of concern is that Epo administration may have detrimental effects on neuronal development inasmuch as Epo induces the proliferation of neuronal stem cells. This may have a negative impact on multipotent progenitor cells because we still need to know their ultimate purpose and role (69). Furthermore, Epo influences apoptosis, which may be an integral component of normal brain development. These issues have not been studied experimentally nor in animals. However, many preterm infants have been studied in large clinical trials and treated with Epo for anemia of prematurity (93-95)

Using high doses of Epo also bears the risk of unwanted effects linked to the chronic overstimulation of EpoR in the bone marrow and other sites. As a procoagulant, Epo can induce coagulation disorders. Adult patients with polycythemia have increased risk for thromboembolic phenomena; however, it has been reported that transgenic mice overexpressing Epo may even be protected against thrombotic disease by Epoinduced erythrocytosis (96). Additionally, long-term consequences of Epo, like red blood cell aplasia, could be derived from the development of Epo antibodies. This has not been described in neonates, but it has been reported in adult patients (97). Other potential side effects of exogenous Epo include polycythemia, proangiogenic undesired effects, switch of endogenous Epo production, hypertension, edema, pyrexia, and gastrointestinal effects, like vomiting, diarrhea, and necrotizing enterocolitis. The clinical trials of Epo in infants (93-95) have neither reported thrombotic events, red blood cell aplasia, development of Epo antibodies nor severe side effects, but the individual doses used are relatively low, and Epo for anemia of prematurity is usually not begun early in postnatal life. In a long-term study, there were no detectable neurodevelopmental deleterious effects of Epo (98), but unpublished reports suggest poor visual outcome of children treated with Epo for anemia of prematurity.

Biodistribution barriers. The ability of Epo to penetrate the BBB is central to its application as a neuroprotective agent in clinical settings. Transport of protein to the brain's extracellular environment via systemic blood supply generally does not occur due to the negligible permeability of the intact brain capillary endothelial wall. Raised concentrations of Epo have been found in the cerebral spinal fluid of infants suffering from ischemic brain injury, when the BBB is altered (99). Interestingly, Epo concentrations were not raised in children with meningitis, suggesting that Epo production may be inhibited by pro-inflammatory cytokines (99). When given at doses appropriate for erythropoiesis (200-400 U/kg per dose), Epo does not cross the BBB in a detectable amount (100). However, Epo given systemically produces cerebrospinal fluid concentrations 
ranging from 50 to $350 \mathrm{mU} / \mathrm{mL}$ at $3-3.5 \mathrm{~h}$ after injection in adult rodents and nonhuman primates (100) and crosses the BBB raising CSF levels by $100 \mathrm{mU} / \mathrm{mL}$ in $30 \mathrm{~min}$ when given in suprapharmacological doses $(2000-5000 \mathrm{U} / \mathrm{kg}$ per dose) $(70,101,102)$. The pharmacokinetics of systemically administered Epo under conditions of the CNS injury, and disruption of the BBB still needs to be clarified. There is also controversy as to whether Epo crosses the placenta. It is described that Epo does not cross the placenta, and that fetal kidneys, liver, and placenta express the Epo gene (103). However, intraperitoneal injection of Epo in pregnant rats has been shown to be neuroprotective (104). To pharmacologically exploit and fully realize the therapeutic benefits of exogenous Epo agents in the CNS dysfunction, mechanisms of action and the potential impact of biodistribution barriers need to be elucidated.

\section{PROMISING OUTLOOK FOR CLINICAL EVALUATION OF EPO IN INJURY TO THE DEVELOPING BRAIN}

Given its multiple biologic functions in the CNS and the fact that it has already been found beneficial in adults with ischemic stroke in a clinical proof of concept study (101), Epo can be considered a novel clinical agent potentially useful in injury to the developing brain. Even though in a small trial (101) using $33,000 \mathrm{U} / \mathrm{d}$ for $3 \mathrm{~d}$ and in clinical administration in patients with anemia and chronic kidney diseases Epo has been well tolerated and safe, caution must be taken in future clinical applications of Epo due to the potential adverse events mentioned above. To limit potential toxicity and to remove erythropoietic activity, derivations of Epo, such as asialoEpo, carbamylated Epo and neurotrophic sequences of Epo, have been developed. Whether Epo, or any of its derivatives that are tissue protective but not erythropoietic, by itself or in combination with other therapies will be both safe and of clinical value in perinatal brain injury remains to be determined in clinical trials. Before institution of these trials, it is necessary to better understand dosing, pharmacokinetics, and window of effectiveness, and to further elucidate mechanisms of action and the role, if any, of biodistribution barriers. Clinical trials should be randomized and masked, and be designed with sufficient sample size to evaluate effects of Epo in prevention and treatment as well as safety and optimal dosage and dosing interval. A pharmacokinetic study (105) has shown that preterm infants compared with adults have greater Epo plasma clearance and volume of distribution, shorter fractional elimination times, nonlinear elimination, and a half-life $40 \%$ that of adults after a dose of $500 \mathrm{U} / \mathrm{kg}$. However, further information is necessary to determine adequate dosing and interval and whether "high doses," which may be protective to the developing brain, are safe in the newborn.

Potential future trials may be of preventive nature and include premature infants at very high risk for IVH, PVL, and severe long-term sequelae. Randomization should be early and Epo once per day or placebo be started by $4-6 \mathrm{~h}$ of age with doses possibly ranging between $1000-5000 \mathrm{U} / \mathrm{kg} / \mathrm{d}$ for the first 72-96 h. In term infants with asphyxia and HI, Epo can be evaluated by itself or in combination with potentially effective therapies, like hypothermia. In this potential trial, inclusion criteria should be clearly defined and Epo at similar daily doses started early and continued for 72-96 h. For therapy in stroke, seizures, trauma, meningitis, or other injuries, infants need to be identified, entered, and treated as early as possible, perhaps with doses in the higher end and for at least 4-7 d. In all these studies, outcome variables should include meticulous neuroimaging, detailed long-term neurodevelopmental assessment and thorough evaluation of undesired adverse effects.

\section{CONCLUSION}

In summary Epo is a potential neurotherapeutic agent that opens a novel way for clinical investigations in protection to the developing brain. Epo seems to affect common initiating mechanisms, like cerebrovascular autoregulation and cerebral ischemia, as well as common downstream mechanisms and free radical attack and it is suggested that both neuronal and oligodendroglial injury could be ameliorated. Further clinical value in perinatal brain injury still needs to be determined.

\section{REFERENCES}

1. Wood NS, Marlow N, Costeloe K, Gibson AT, Wilkinson AR 2000 Neurologic and developmental disability after extremely preterm birth. EPICure Study Group. N Engl J Med 343:378-384

2. Vannucci RC 2000 Hypoxic-ischemic encephalopathy. Am J Perinatol 17:113-120

3. Edwards AD, Azzopardi DV 2000 Perinatal hypoxia-ischemia and brain injury. Pediatr Res 47:431-432

4. Lynch JK, Hirtz DG, DeVeber G, Nelson KB 2002 Report of the National Institute of Neurological Disorders and Stroke workshop on perinatal and childhood stroke. Pediatrics 109:116-123

5. Lynch JK, Nelson KB 2001 Epidemiology of perinatal stroke. Curr Opin Pediatr 13:499-505

6. Stillger A, Kumar RK 1999 Neonatal cerebral infarction: USS or CT for imaging? Indian J Pediatr 66:141-143

7. Nelson KB, Lynch JK 2004 Stroke in newborn infants. Lancet Neurol 3:153-158

8. Ramaswamy V, Miller SP, Barkovich AJ, Partridge JC, Ferriero DM 2004 Perinatal stroke in term infants with neonatal encephalopathy. Neurology 62:2088-2091

9. Volpe JJ 2001 Neurobiology of periventricular leukomalacia in the premature infant. Pediatr Res 50:553-562

10. Lemons JA, Bauer CR, Oh W, Korones SB, Papile LA, Stoll BJ, Verter J, Temprosa M, Wright LL, Ehrenkranz RA, Fanaroff AA, Stark A, Carlow W, Tyson JE Donovan FF, Shankaran S, Stevenson DK 2001 Very low birth weight outcomes of the National Institute of Child Health and Human Development Neonatal Research Network, January 1995 through December 1996. NICHD Neonatal Research Network. Pediatrics 107:El

11. Ferriero DM 2004 Neonatal brain injury. N Engl J Med 351:1985-1995

12. Volpe JJ 2001 Perinatal brain injury: from pathogenesis to neuroprotection. Ment Retard Dev Disabil Res Rev 7:56-64

13. Jensen A, Garnier Y, Middelanis J, Berger R 2003 Perinatal brain damage-from pathophysiology to prevention. Eur J Obstet Gynecol Reprod Biol 110(suppl 1):S70-S79

14. Hamrick SE, Ferriero DM 2003 The injury response in the term newborn brain: can we neuroprotect? Curr Opin Neurol 16:147-154

15. McQuillen PS, Ferriero DM 2004 Selective vulnerability in the developing central nervous system. Pediatr Neurol 30:227-235

16. Aboul-Enein F, Rauschka H, Kornek B, Stadelmann C, Stefferl A, Bruck W, Lucchinetti C, Schmidbauer M, Jellinger K, Lassmann H 2003 Preferential loss of myelin-associated glycoprotein reflects hypoxia-like white matter damage in stroke and inflammatory brain diseases. J Neuorpathol Exp Neurol 62:25-33

17. Walton M, Connor B, Lawlor B, Young D, Sirimanne E, Gluckman P Cole G, Dragunow M 1999 Neuronal death and survival in two models of hypoxic-ischemic brain damage. Brain Res Brain Res Rev 29:137-168

18. Aito H, Aalto KT, Raivio KO 2002 Biphasic ATP depletion caused by transient oxidative exposure is associated with apoptotic cell death in rat embryonal cortical neurons. Pediatr Res 52:40-45

19. Grether JK, Nelson KB 1997 Maternal infection and cerebral palsy in infants of normal birth weight. JAMA 278:207-211

20. Marret S, Gressens P, Evrard P 1996 Neuronal migration disorders induced by ibotenate in the neocortex. Proc Natl Acad Sci U S A 17:543-551

21. Marret S, Mukendi R, Gadisseux JF, Gressens P, Evrard P 1995 Effect of ibotenate on brain development: an excitotoxic mouse model of microgyria and posthypoxic like lesions. J Neuropathol Exp Neurol 54:358-370 
22. Gressens P, Marret S, Evrard P 1996 Developmental spectrum of the excitotoxic cascade induced by ibotenate: a model of hypoxic insults in fetuses and neonates. Neuropathol Appl Neurobiol 22:498-502

23. Tahraoui SL, Marret S, Bodénant C, Leroux P, Dommergues MA, Evrard P, Gressens P 2001 Central role of microglia in neonatal excitotoxic lesions of the murine periventricular white matter. Brain Pathol 11:56-71

24. Dommergues MA, Plaisant F, Verney C, Gressens P 2003 Early microglial activation following neonatal excitotoxic brain damage in mice: a target for neuroprotection. Neuroscience 121:619-628

25. Follett PL, Rosenberg PA, Volpe JJ, Jensen FE 2000 NBQX attenuates excitotoxic injury in developing white matter. J Neurosci 20:9235-9241

26. Xu H, Barks JD, Liu YQ, Silverstein FS 2001 AMPA-induced suppression of oligodendroglial gene expression in neonatal rat brain. Brain Res Dev Brain Res $132 \cdot 175-180$

27. Nelson KB, Grether JK, Dambrosia JM, Walsh E, Kohler S, Satyanarayana G, Nelson PG, Dickens BF, Phillips TM 2003 Neonatal cytokines and cerebral palsy in very preterm infants. Pediatr Res 53:600-607

28. Dommergues MA, Patkai J, Renauld JC, Evrard P, Gressens P 2000 Proinflammatory cytokines and interleukin- 9 exacerbate excitotoxic lesions of the newborn murine neopallium. Ann Neurol 47:54-63

29. Plaisant F, Dommergues MA, Campbell IL, Gressens P 2002 Effects of systemic and CNS pro-inflammatory cytokines on NMDA and AMPA receptors-mediated brain lesions in newborn mice. Pediatr Res 51:442A

30. Gressens P, Rogido M, Paindaveine B, Sola A 2002 The impact of neonatal intensive care practices on the developing brain. J Pediatr 140:646-653

31. Mesplès B, Plaisant F, Gressens P 2003 Effects of interleukin-10 on neonata excitotoxic brain lesions in mice. Brain Res Dev Brain Res 141:25-32

32. Patkai J, Mesplès B, Dommergues MA, Fromont G, Thornton EM, Renauld JC, Evrard P Gressens P 2001 Deleterious effects of IL-9-activated mast cells and neuroprotection by antihistamine drugs in the developing mouse brain. Pediatr Res 50:222-230

33. Mesplès B, Fontaine RH, Lelièvre V, Launay JM, Gressens P 2005 Neurona TGF- $\beta 1$ mediates IL-9/mast cell interaction and exacerbate excitotoxicity in newborn mice. Neurobiol Dis 18:193-205

34. Palmer C, Towfighi J, Roberts RL, Heitjan DF 1993 Allopurinol administered after inducing hypoxia-ischemia reduces brain injury in 7-day-old rats. Pediatr Res 33:405-411

35. Van Bel F, Shadid M, Moison RM, Dorrepaal CA, Fontijn J, Monteiro L, Van De Bor M, Berger HM 1998 Effect of allopurinol on postasphyxial free radica formation, cerebral hemodynamics, and electrical brain activity. Pediatrics 101:185193

36. Hamada Y, Hayakawa T, Hattori H, Mikawa H 1994 Inhibitor of nitric oxide synthesis reduces hypoxic-ischemic brain damage in the neonatal rat. Pediatr Res 35:10-14

37. Ferriero DM, Holtzman DM, Black SM, Sheldon RA 1996 Neonatal mice lacking neuronal nitric oxide synthase are less vulnerable to hypoxic-ischemic injury. Neurobiol Dis 3:64-71

38. Nelson KB, Grether JK 1995 Can magnesium sulfate reduce the risk of cerebra palsy in very low birthweight infants? Pediatrics 95:263-269

39. Schendel DE, Berg CJ, Yeargin-Allsopp M, Boyle CA, Decoufle P 1996 Prenata magnesium sulfate exposure and risk for cerebral palsy or mental retardation among very low-birth-weight children aged 3 to 5 years. JAMA 276:1805-1810

40. Levene M, Blennow M, Whitelaw A, Hanko E, Fellman V, Hartley R 1995 Acute effects of two different doses of magnesium sulphate in infants with birth asphyxia. Arch Dis Child Fetal Neonatal Ed 73:F174-F177

41. Ichiba H, Tamai H, Negishi H, Ueda T, Kim TJ, Sumida Y, Takahashi Y, Fujinaga H, Minami H, Kansai Magnesium Study Group 2002 Randomized controlled trial of magnesium sulfate infusion for severe birth asphyxia. Pediatr Int 44:505-509

42. Garnier Y, Middelanis J, Jensen A, Berger R 2002 Neuroprotective effects of magnesium on metabolic disturbances in fetal hippocampal slices after oxygenglucose deprivation: mediation by nitric oxide system. J Soc Gynecol Investig 9:86-92

43. Sola A, Berrios M, Sheldon RA, Ferriero DM, Gregory GA 1996 Fructose-1,6 bisphosphate after hypoxic ischemic injury is protective to the neonatal rat brain Brain Res 741:294-299

44. Rogido M, Husson I, Bonnier C, Lallemand MC, Merienne C, Gregory GA, Sola A Gressens P 2003 Fructose-1, 6 bisphosphate prevents excitotoxic neuronal cell death in the neonatal mouse brain. Brain Res Dev Brain Res 140:287-297

45. Gunn AJ, Gluckman PD, Gunn TR 1998 Selective head cooling in newborn infants after perinatal asphyxia: a safety study. Pediatrics 102:885-892

46. Azzopardi D, Robertson NJ, Cowan FM, Rutherford MA, Rampling M, Edwards AD 2000 Pilot study of treatment with whole body hypothermia for neonatal encephalopathy. Pediatrics 106:684-694

47. Battin MR, Penrice J, Gunn TR, Gunn AJ 2003 Treatment of term infants with head cooling and mild systemic hypothermia (35.0 degrees $\mathrm{C}$ and 34.5 degrees $\mathrm{C}$ ) after perinatal asphyxia. Pediatrics 111:244-251

48. Gluckman PD, Wyatt JS, Azzopardi RB, Ballard R, Edwards D, Ferriero DM, Polin RA, Robertson C, Thoresen M, Whitelaw A, Gunn AJ, the CoolCap Study 2004 Selective head cooling with mild systemic hypothermia to improve neurodevelopmental outcome following neonatal encephalopathy. Pediatr Res 55:582A

49. Shankaran S, Laptook AR, Ehrenkranz RA, Donovan EA, Fanaroff AA, Tyson JE, McDonald SA, Poole K, Wright LL, Goldberg R, NICHD, Neonatal Research Network 2004 Safety of whole body hypothermia for hypoxic-ischemic encephalopathy (HIE). Pediatr Res 55:582A
50. Sheldon RA, Jiang X, Francisco C, Christen S, Vexler ZS, Täuber MG, Ferriero DM 2004 Manipulation of antioxidant pathways in neonatal murine brain. Pediatr Res $56: 656-662$

51. Fisher JW 2003 Erythropoietin: physiology and pharmacology update. Exp Biol Med 228:1-14

52. Liu C, Shen K, Liu Z, Noguchi CT 1997 Regulated human erythropoietin receptor expression in mouse brain. J Biol Chem 272:32395-32400

53. Juul SE, Anderson DK, Li Y, Christensen RD 1998 Erythropoietin and erythropoietin receptor in the developing human central nervous system. Pediatr Res 43:40-49

54. Wu H, Lee SH, Gao J, Liu X, Iruela-Arispe ML1999 Inactivation of erythropoietin leads to defects in cardiac morphogenesis. Development 126:3597-3605

55. Yu X, Shacka JJ, Eells JB, Suarez-Quian C, Przygodzki RM, Beleslin-Cokic B, Lin CS, Nikodem VM, Hempstead B, Flanders KC, Costantini F, Noguchi CT 2002 Erythropoietin receptor signaling is required for normal brain development. Development 129:505-516

56. Jelkmann W 1992 Erythropoietin: structure, control of production, and function Physiol Rev 72:449-489

57. Masuda S, Nagao N, Takahata K, Konishi Y, Gallyas F Jr, Tabira T, Sasaki R 1993 Functional erythropoietin receptor of the cells with neural characteristics. Comparison with receptor properties of erythroid cells. J Biol Chem 268:11208-11216

58. Lewczuk P, Hasselblatt M, Kamrowski-Kruck H, Heyer A, Unzicker C, Siren AL, Ehrenreich H 2000 Survival of hippocampal neurons in culture upon hypoxia: effect of erythropoietin. NeuroReport 11:3485-3488

59. Siren AL, Fratelli M, Brines M, Goemans C, Casagrande S, Lewczuk P, Keenan S, Gleiter C, Pasquali C, Capobianco A, Mennini T, Heumann R, Cerami A, Ehrenreich H, Ghezzi P 2001 Erythropoietin prevents neuronal apoptosis after cerebral ischemia and metabolic stress. Proc Natl Acad Sci U S A 98:4044-4049

60. Marti HH, Wenger RH, Rivas LA, Straumann U, Digicaylioglu M, Henn V, Yonekawa Y, Bauer C, Gassmann M 1996 Erythropoietin gene expression in human, monkey and human brain. Eur J Neurosci 8:666-676

61. SadamotoY, Igase K, Sakanaka M, Sato K, Otsuka H, Sakaki S, Masuda S, Sasaki R1998 Erythropoietin prevents place navigation disability and cortical infarction in rats with permanent occlusion of the middle cerebral artery. Biochem Biophys Res Commun 253:26-32

62. Bernaudin M, Marti HH, Roussel S, Divoux D, Nouvelot A, MacKenzie ET, Petit E 1999 A potential role for erythropoietin in focal permanent cerebral ischemia in mice. J Cereb Blood Flow Metab 19:643-651

63. Siren AL, Knerlich F, Poser W, Gleiter CH, Bruck W, Ehrenreich H 2001 Erythropoietin and erythropoietin receptor in human ischemic/hypoxic brain. Acta Neuropathol (Berl) 101:271-276

64. Wen TC, Rogido M, Gressens P, Sola A 2004 A reproducible experimental model of focal cerebral ischemia in the neonatal rat. Brain Res Brain Res Protocol $13: 76-83$

65. Wen TC, Rogido M, Genetta T, Sola A 2004 Permanent focal cerebral ischemia activates erythropoietin receptor in the neonatal rat brain. Neurosci Lett 355:165168

66. Morishita E, Masuda S, Nagao M, Yasuda Y, Sasaki R 1997 Erythropoietin receptor is expressed in rat hippocampal and cerebral cortical neurons, and erythropoietin prevents in vitro glutamate-induced neuronal death. Neuroscience 76:105-116

67. Sakanaka M, Wen TC, Matsuda S, Masuda S, Morishita E, Nagao M, Sasaki R 1998 In vivo evidence that erythropoietin protects neurons from ischemic damage. Proc Natl Acad Sci U S A 95:4635-4640

68. Sinor AD, Greenberg DA 2000 Erythropoietin protects cultured cortical neurons, but not astroglia, from hypoxia and AMPA toxicity. Neurosci Lett 290:213-215

69. Shingo T, Sorokan ST, Shimazaki T, Weiss S 2001 Erythropoietin regulates the in vitro and in vivo production of neuronal progenitors by mammalian forebrain neural stem cells. J Neurosci 21:9733-9743

70. Brines ML, Ghezzi P, Keenan S, Agnello D, de Lanerolle NC, Cerami C, Itri LM, Cerami A 2000 Erythropoietin crosses the blood-brain barrier to protect against experimental brain injury. Proc Natl Acad Sci U S A 97:10526-10531

71. Wen TC, Sadamoto Y, Tanaka J, Zhu PX, Nakata K, Ma YJ, Hata R, Sakanaka M 2002 Erythropoietin protects neurons against chemical hypoxia and cerebral ischemic injury by up-regulating Bcl-xL expression. J Neurosci Res 67:795-803

72. Digicaylioglu M, Kaul M, Fletcher L, Dowen R, Lipton SA 2004 Erythropoietin protects cerebrocortical neurons from HIV-1/gp120-induced damage. Neuroreport 15:761-763

73. Kumral A, Ozer E, Yilmaz O, Akhisaroglu M, Gokmen N, Duman N, Ulukus C, Genc S, Ozkan H 2003 Neuroprotective effect of erythropoietin on hypoxic-ischemic brain injury in neonatal rats. Biol Neonate 83:224-228

74. Aydin A, Genc K, Akhisaroglu M, Yorukoglu K, Gokmen N, Gonullu E 2003 Erythropoietin exerts neuroprotective effect in neonatal rat model of hypoxicischemic brain injury. Brain Dev 25:494-498

75. Matsushita H, Johnston MV, Lange MS, Wilson MA 2003 Protective effect of erythropoietin in neonatal hypoxic ischemia in mice. Neuroreport 14:1757-1761

76. Sun Y, Zhou C, Polk P, Nanda A, Zhang JH 2004 Mechanisms of erythropoietininduced brain protection in neonatal hypoxia-ischemia rat model. J Cereb Blood Flow Metab 24:259-270

77. Spandou E, Soubasi V, Papoutsopoulou S, Karkavelas G, Simeonidou C, KaikiAstara A, Guiba-Tziampiri O 2004 Erythropoietin prevents hypoxia/ischemiainduced DNA fragmentation in an experimental model of perinatal asphyxia. Neurosci Lett 366:24-28

78. Solaroglu I, Solaroglu A, Kaptanoglu E, Dede S, Haberal A, Beskonakli E, Kilinc K 2003 Erythropoietin prevents ischemia-reperfusion from inducing oxidative damage in fetal rat brain. Childs Nerv Syst 19:19-22

79. Wang CH, Liang CL, Huang LT, Liu JK, Hung PH, Sun A, Hung KS ingle intravenous injection of naked plasmid DNA encoding erythropoietin provides 
neuroprotection in hypoxia-ischemia rats. Biochem Biophys Res Commun 314:1064-1071, 2004S

80. Sola A, Rogido M, Lee B, Genetta T, Wen TC 2005 Erythropoietin after foca cerebral ischemia activates the Jak-Stat signaling pathway and improves brain injury in postnatal day-7 rats. Pediatr Res 57:481-487

81. Kumral A, Uysal N, Tugyan K, Sonmez A, Yilmaz O, Gokmen N, Kiray M, Genc S, Duman N, Koroglu TF, Ozkan H, Genc K 2004 Erythropoietin improves long-term spatial memory deficits and brain injury following neonatal hypoxiaischemia in rats. Behav Brain Res 153:77-86

82. Chang YS, Mu D, Wendland M, Sheldon RA, Vexler ZA, McQuillen PS, Ferriero DM 2005 Erythropoietin improves functional and histological outcome in neonata stroke. Pediatr Res, in press

83. Digicaylioglu M, Lipton SA 2001 Erythropoietin-mediated neuroprotection involves cross-talk between Jak2 and NF-kappaB signalling cascades. Nature 412:641-647

84. Kumral A, Baskin H, Gokmen N, Yilmaz O, Genc K, Genc S, Tatli MM, Duman N, Ozer E, Ozkan H 2004 Selective inhibition of nitric oxide in hypoxic-ischemic brain model in newborn rats: is it an explanation for the protective role of erythropoietin? Biol Neonate 85:51-54

85. Ribatti D, Presta M, Vacca A, Ria R, Giuliani R, Dell'Era P, Nico B, Roncali L, Dammacco F 1999 Human erythropoietin induces a pro-angiogenic phenotype in cultured endothelial cells and stimulates neovascularization in vivo. Blood 93:26272636

86. Gorio A, Gokmen N, Erbayraktar S, Yilmaz O, Madaschi L, Cichetti C, Di Giulio AM, Vardar E, Cerami A, Brines M 2002 Recombinant human erythropoietin counteracts secondary injury and markedly enhances neurological recovery from experimental spinal cord trauma. Proc Natl Acad Sci U S A 99:9450-9455

87. Cattaneo E, Conti L, De-Fraja 1999 Signalling through the JAK-STAT pathway in the developing brain. Trends Neurosci 22:365-369

88. Kawakami M, Sekiguchi M, Sato K, Kozaki S, Takahashi M 2000 Erythropoietin receptor-mediated inhibition of exocytotic glutamate release confers neuroprotection during chemical ischemia. J Biol Chem 276:39469-39475

89. Campana WM, Misasi R, O'Brien JS 1998 Identification of a neurotrophic sequence in erythropoietin. Int J Mol Med 1:235-241

90. Leist M, Ghezzi P, Grasso G, Bianchi R, Villa P, Fratelli M, Savino C, Bianchi M, Nielsen J, Gerwien J, Kallunki P, Larsen AK, Helboe L, Christensen S, Pedersen LO, Nielsen M, Torup L, Sager T, Sfacteria A, Erbayraktar S, Erbayraktar Z, Gokmen N, Yilmaz O, Cerami-Hand C, Xie QW, Coleman T, Cerami A, Brines M 2004 Derivatives of erythropoietin that are tissue protective but not erythropoietic. Science 305:239-242

91. Brines M, Grasso G, Fiordaliso F, Sfacteria A, Ghezzi P, Fratelli M, Latini R, Xie QW, Smart J, Su-Rick CJ, Pobre E, Diaz D, Gomez D, Hand C, Coleman T, Ceram A 2004 Erythropoietin mediates tissue protection through an erythropoietin and common beta-subunit heteroreceptor. Proc Natl Acad Sci U S A 101:14907-14912

92. Dzietko M, Felderhoff-Mueser U, Sifringer M, Krutz B, Bittigau P, Thor F, Heumann R, Buhrer C, Ikonomidou C, Hansen HH 2004 Erythropoietin protects the developing brain against $\mathrm{N}$-methyl-D-aspartate receptor antagonist neurotoxicity. Neurobiol Dis 15:177-187
93. Shannon KM, Keith JF III, Mentzer WC, Ehrenkranz RA, Brown MS, Widness JA, Gleason CA, Bifano EM, Millard DD, Davis CB 1995 Recombinant human erythropoietin stimulate erythropoiesis and reduces erythrocyte transfusions in very low birth weight preterm infants. Pediatrics 95:1-8

94. Meyer MP, Meyer JH, Commerford A, Hann FM, Sive AA, Moller G, Jacobs P, Malan AF 1994 Recombinant human erythropoietin in the treatment of the anemia of prematurity: results of a double-blind, placebo-controlled study. Pediatrics 93:918-923

95. Maier RF, Obladen M, Kattner E, Natzschka J, Messer J, Regazzoni BM, Speer CP, Fellman V, Grauel EL, Groneck P, Wagner M, Moriette G, Salle BL, Verellen G, Scigalla P 1998 High- versus low-dose erythropoietin in extremely low birth weight infants. The European Multicenter rhEPO Study Group. J Pediatr 132:866-870

96. Shibata J, Hasegawa J, Siemens HJ, Wolber E, Dibbelt L, Li D, Katschinski DM, Fandrey J, Jelkmann W, Gassmann M, Wenger RH, Wagner KF 2003 Hemostasis and coagulation at a hematocrit level of 0.85 : functional consequences of erythrocytosis. Blood 101:4416-4422

97. Casadevall N, Nataf J, Viron B, Kolta A, Kiladjian JJ, Martin-Dupont P, Michaud P, Papo T, Ugo V, Teyssandier I, Varet B, Mayeux P 2002 Pure red-cell aplasia an antierythropoietin antibodies in patients treated with recombinant erythropoietin. N Engl J Med 346:469-475

98. Newton NR, Leonard CH, Piecuch RE, Phibbs RH 1999 Neurodevelopmental outcome of prematurely born children treated with recombinant human erythropoietin in infancy. J Perinatol 19:403-406

99. Juul SE, Stallings SA, Christensen RD 1999 Erythropoietin in the cerebrospinal fluid of neonates who sustained CNS injury. Pediatr Res 46:543-547

100. Juul SE 2002 Erythropoietin in the central nervous system, and its use to prevent hypoxic-ischemic brain damage. Acta Paediatr 438:36-42

101. Ehrenreich H, Hasselblatt M, Dembowski C, Cepek L, Lewczuk P, Stiefel M, Rustenbeck HH, Breiter N, Jacob S, Knerlich F, Bohn M, Poser W, Ruther E, Kochen M, Gefeller O, Gleiter C, Wessel TC, De Ryck M, Itri L, Prange H, Cerami A, Brines M, Siren AL 2002 Erythropoietin therapy for acute stroke is both safe and beneficial. Mol Med 8:495-505

102. Ehrenreich H, Degner D, Meller J, Brines M, Behe M, Hasselblatt M, Woldt H, Falkai P, Knerlich F, Jacob S, von Ahsen N, Maier W, Bruck W, Ruther E, Cerami A, Becker W, Siren AL 2004 Erythropoietin: a candidate compound for neuroprotection in schizophrenia. Mol Psychiatry 9:42-54

103. Davis LE, Widness JA, Brace RA 2000 Renal and placental secretion of erythropoietin during anemia or hypoxia in the ovine fetus. Am J Obstet Gynecol 189:1764-1770

104. Solaroglu I, Solaroglu A, Kaptanoglu E, Dede S, Haberal A, Beskonakli E, Kilinc K 2003 Erythropoietin prevents ischemia-reperfusion from inducing oxidative damage in fetal rat brain. Childs Nerv Syst 19:19-22

105. Widness JA, Veng-Pedersen P, Peters C, Pereira LM, Schmidt RL, Lowe LS 1996 Erythropoietin pharmacokinetics in premature infants: developmental, nonlinearity, and treatment effects. J Appl Physiol 80:140-148 